\title{
Karakteristik Temperatur Pada Permukaan Sel Surya Polycrystalline Terhadap Efektifitas Daya Keluaran Pembangkit Listrik Tenaga Surya
}

\author{
Andi Makkulau'; Samsurizal'² Salvatore Kevin ${ }^{3}$ \\ 1, 2, 3 Teknik Elektro, Institut Teknologi PLN \\ ${ }^{2}$ samsurizal@itpln.ac.id
}

\begin{abstract}
Devices that can convert sunlight energy to electrical energy with photovoltaic effect process made of semiconductors are better known as solar cells. Photovoltaic (PV) or better known as solar power plant (PLTS) is also concerned with several factors to maximize solar energy into electrical energy such as the influence of weather, humidity, temperature of solar cell position and wind direction contained on the surface of solar cells. In this study, this solar cell (photovoltaic) was diagnosed as poly-crystalline during sunny and cloudy weather conditions. The results obtained by the test showed the influence of temperature from the surface of solar cells on the value of output power. Maximum power (Pout) at 11.40 WIB with a slope angle of $35^{\circ}$ and a temperature of $47.6^{\circ} \mathrm{C}$ with an output power value of 100.562 Watt. So it can be said that the temperature is influenced by the intensity of solar radiation that will make the power (Pout) increase, the condition of the poly-crystalline solar module will work optimally at a temperature of about $35^{\circ} \mathrm{C}-50^{\circ} \mathrm{C}$ measured on the surface of solar cells.
\end{abstract}

Keywords: Photovoltaic, Temperature, Power Output, Poly-Crystalline

\section{ABSTRAK}

Perangkat yang dapat merubah energi sinar matahari ke energi listrik dengan proses efek Photovoltaic berbahan semikonduktor lebih kita kenal dengan istilah sel surya. Photovoltaic (PV) atau yang lebih dikenal dengan istilah pembangkit listrik tenaga surya (PLTS) ini juga memperhatikan beberapa faktor untuk memaksimalkan energi surya menjadi energi listrik yaitu seperti pengaruh cuaca, kelembaban, temperatur posisi sel surya serta arah angin yang terdapat pada permukaan sel surya. Pada penelitian ini sel surya (photovoltaic) ini yang diuijkan berjenis poly-crystalline saat kondisi cuaca cerah dan berawan. Hasil yang didapat pengujian menunjukkan pengaruh temperatur dari permukaan sel surya terhadap nilai daya keluarannya. Daya (Pout) maksimal pada pukul 11.40 WIB dengan sudut kemiringan $35^{\circ}$ serta suhu $47,6^{\circ} \mathrm{C}$ dengan nilai daya keluarannya sebesar 100,562 Watt. Sehingga bisa dikatakan suhu dipengaruhi oleh intensitas radiasi matahari yang akan membuat daya (Pout) mengalami kenaikan, kondisi modul surya berjenis poly-crystalline akan bekerja secara optimal pada suhu sekitar $35^{\circ} \mathrm{C}-50^{\circ} \mathrm{C}$ yang terukur pada permukaan sel surya.

Kata Kunci: Photovoltaic, Temperatur, Daya Keluaran, Poly-Crystalline 


\section{JURNAL ILMIAH SUTET}

Vol. 10, No. 2, Desember 2020, P-ISSN 2356-1505, E-ISSN 2656-9175

https://doi.org/10.33322/sutet.v10i2.1291

\section{PENDAHULUAN}

Sejalan dengan semakin berkembangnya teknologi semakin besar pula energi yang dibutuhkan manusia[1][2]. Namun disaat yang sama energi fosil yang tersedia tidaklah banyak sehingga manusia harus mengubah tren produksi dan penggunaan bahan bakar, dari bahan bakar fosil ke bahan bakar non fosil atau energi terbarukan, yang didapat dari luar secara bebas seperti energi surya, energi angin, energi kinetik, energi panas. Sel surya merupakan sebuah perangkat yang dapat merubah energi sinar matahari ke energi listrik dengan proses efek fotovoltaik dengan berbahan semi konduktor, komponen panel surya atau solar cell ini sangat penting bagi sistem pembangkit listrik tenaga surya[3][7]. Photovoltaic (PV) atau yang lebih dikenal dengan istilah pembangkit listrik tenaga surya (PLTS) menjadi salah satu alternatif yang menjadi topik pilihan untuk terus dikembangkan. Photovoltaic atau sel surya dianggap sebagai PLTS yang menjanjikan karena beberapa alasan, yaitu bebas polusi, sumber energinya dapat diperoleh secara gratis dan banyak tersedia di alam. Adanya perkembangan yang simultan pada bidang teknologi bahan serta elektronik, yang bermanfaat dalam peningkatan efisiensi, juga menjadi alasan utama mengapa penelitian di bidang PV semakin gencar dan terus berkembang. Pembangkit Listrik Tenaga Surya (PLTS) ini juga memperhatikan memperhatikan beberapa faktor untuk memaksimalkan energi surya menjadi energi listrik yaitu seperti pengaruh cuaca, kelembaban, temperatur posisi sel surya serta arah angin yang terdapat pada permukaan sel surya[5][6].

Pada sel surya ini yang dimana dapat mengubah energi matahari menjadi energi listrik dan dapat menjadi sumber energi yang berguna maka salah satu faktornya adalah effisiensinya harus tinggi. Salah satu bagian terpenting dalam yang menjaga tingkat effisiensi yang tinggi adalah sel surya (photovoltaic)[9][11]. Namun pada dasarnya masih kurang diperhatikan cara mempertahankan suhu lapisan pada permukaan sel surya (photovoltaic) yang dapat mengganggu proses efek photovoltaic yang dimana merupakan fenomena dimana energi cahaya datang, yang mengenai permukaan sel surya akan diubah menjadi energi listrik[10][16].

Energi baru dan yang terbarukan mempunyai peran yang sangat penting dalam memenuhi kebutuhan energi. Hal ini disebabkan penggunaan bahan bakar untuk pembangkit-pembangkit listrik konvensional dalam jangka waktu yang panjang akan menguras sumber minyak bumi, gas dan batu bara yang makin menipis dan juga dapat mengakibatkan pencemaran lingkungan[12][15]. Salah satunya upaya yang telah dikembangkan adalah Pembangkit Listrik Tenaga Surya (PLTS) atau yang lebih dikenal dengan sel surya sel fotovoltaik akan lebih diminati karena dapat digunakan untuk berbagai keperluan yang relevan dan di berbagai tempat seperti perkantoran, pabrik, perumahan, dan lainnya. Di Indonesia yang merupakan daerah tropis mempunyai potensi energi matahari sangat besar dengan insolasi harian rata-rata $4,5-4,8 \mathrm{KWh} / \mathrm{m}^{2}$ / hari[11][17]. Akan tetapi energi listrik yang dihasilkan sel surya sangat dipengaruhi oleh intensitas cahaya matahari yang diterima oleh system[10][13]. Penelitian kali ini memabahas pengujian sel surya (photovoltaic) dengan memperhatikan daya keluarannya. sertakKarakteristik suhu pada permukaan sel surya (photovoltaic).

\section{METODE PENELITIAN}

Sel Surya diproduksi dari bahan semikonduktor yaitu silikon yang berperan sebagai insulator pada temperatur rendah dan sebagai konduktor bila ada energi dan panas. 
Sebuah silikon sel surya adalah sebuah diode yang terbentuk dari 3 lapisan atas silikon tipe $\mathrm{n}$ (silicon doping of "phosphorous"), dan lapisan bawah silikon tipe $\mathrm{p}$ (silicon doping of "boron"). Elektron-elektron bebas terbentuk dari milion photon atau benturan atom pada lapisan penghubung (junction=0.2-0.5 mikron) menyebabkan terjadinya aliran listrik. Sebuah sel surya dalam menghasilkan energi listrik (energi sinar matahari menjadi photon) tidak tergantung pada besaran luas bidang silikon, dan secara konstan akan menghasilkan energi berkisar \pm 0.5 voltmax. $600 \mathrm{mV}$ pada $2 \mathrm{amp}$, dengan kekuatan radiasi solar matahari $1000 \mathrm{~W} / \mathrm{m}^{2}$ = "1 Sun" akan menghasilkan arus listrik (I) sekitar $30 \mathrm{~mA} / \mathrm{cm}^{2}$ per sel surya. Sebuah sel surya beroperasi secara normal. Sel surya akanmenghasilkan energi maksimum jika nilai Vm dan Im juga maksimum. Sedangkan Isc adalah arus listrik maksimum pada nilai volt= nol; Isc berbanding langsungengan tersedianya sinar matahari. Voc adalah volt maksimum pada nilai arus nol; Voc naik secara logaritma dengan peningkatan sinar matahari, karakter ini yang memungkinkan sel surya untuk mengisi accu, Dalam Pelaksanaan Penelitian ini, Peneliti menggunakan beberapa tahapan atau metode untuk menyelesaikan penelitian Berikut ini adalah diagram alur dari proses ditunjukkan gambar 1

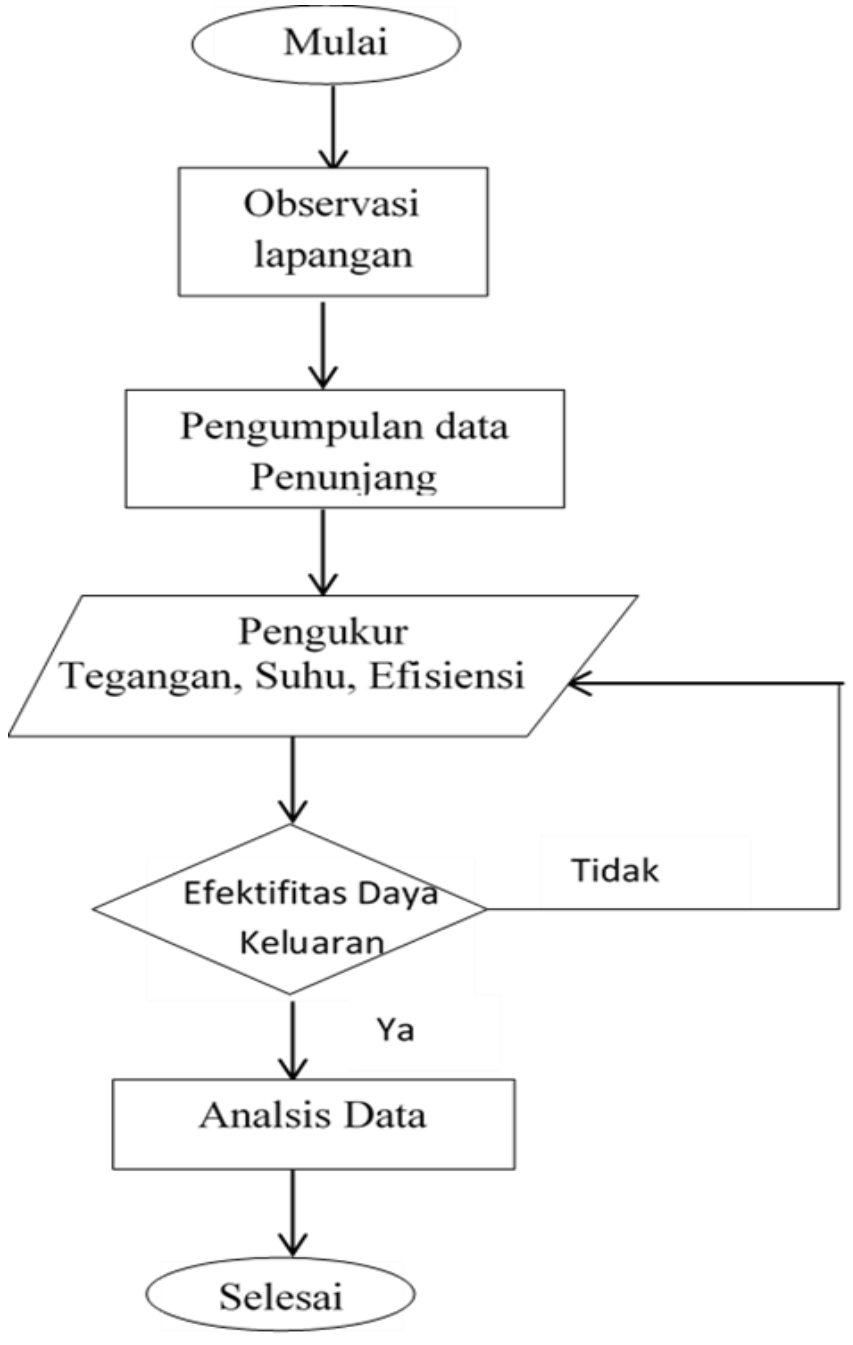

Gambar 1. Diagram Alir Penelitian 
Pada penelitian ini menggunakan metode kuantitatif yang diperlukan beberapa rumus untuk perhitungannya, dilaksanakan dengan tahapan-tahapan sebagai berikut :

Perhitungan Daya Pada Panel Surya

Sebelum mengetahui berapa nilai daya sesaat yang dihasilkan kita harus mengetahui daya yang diterima (daya input), dimana daya tersebut adalah perkalian antara intensitas radiasi matahari yang diterima dengan luas area PV.

$$
\operatorname{Pin}=\operatorname{Ir} \times A
$$

\section{Dimana :}

Pin : : Daya input akibat irradiance matahari (Watt)

Ir $\quad$ : Intensitas radiasi matahari ( Watt $\left./ \mathrm{m}^{2}\right)$

A : Luas area permukaan panel surya $\left(\mathrm{m}^{2}\right)$

Sedangkan untuk besarnya daya pada solar cell (Pout) yaitu perkalian tegangan rangkaian terbuka (Voc), arus hubung singkat (Isc), dan Fill Factor (FF) yang dihasilkan oleh sel surya (photovoltaic) dapat dihitung dengan rumus sebagai berikut :

$$
\text { Pout }=\text { Voc } \times \text { Isc } \times \text { FF }
$$

Dimana :

Pout : Daya yang dibangkitkan oleh sel surya (Watt)

Voc : Tegangan rangkaian terbuka pada sel surya (Volt)

Isc : : Arus hubung singkat pada sel surya (Ampere)

FF : Fill Factor

Nilai FF dapat diperoleh dari rumus :

$$
\mathrm{FF}=\frac{V m p \times I m p}{V o c \times I s c}
$$

Dimana :

Vmp : Maximum Power Voltage ( Volt )

Imp : : Maximum Power Current ( Ampere )

Voc : : Tegangan rangkaian terbuka pada sel surya ( Volt )

Isc : : Arus hubung singkat pada sel surya ( Ampere )

Perhitungan Effisiensi Panel Surya

Effisiensi yang terjadi pada sel surya (photovoltaic) adalah merupakan perbandingan daya yang dapat dibangkitkan oleh sel surya dengan energi inputyang diperoleh oleh irrandiance matahari. Efisiensi

yang digunakan adalah efisiensi sesaat pada pengambilan data.

$$
\eta=\frac{\text { Pout } \times 100 \%}{\text { Pin }}
$$

Dimana :

Pout $\quad$ : Daya yang dibangkitkan oleh sel surya (Watt)

Pin : Daya input akibat irradiance matahari (Watt) 


\section{HASIL DAN PEMBAHASAN}

Dengan menggunakan modul surya jenis polycristaline kapasistas 100wp seperti pada gambar 2. Maka kita dapat melakukan pengujian dan pengukuran sesuai dengan yang ingin kita ketahui.

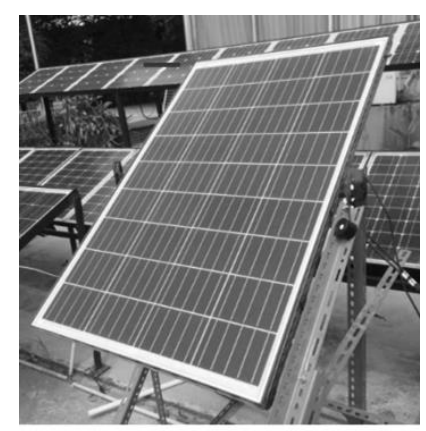

Gambar 2. Modul Pengujian

Dari hasil penguijian dan pengukuran lapangan yang sudah dilakukan didapat hasil yang ditunjukkan pada tabel.1

Tabel 1. Hasil Pengukuran

\begin{tabular}{|c|c|c|c|c|c|c|}
\hline $\begin{array}{c}\text { No. } \\
\left(\mathrm{W} / \mathrm{m}^{2}\right)\end{array}$ & $\begin{array}{c}\text { Waktu } \\
\text { (A) }\end{array}$ & $\begin{array}{c}\text { Iradiasi } \\
\text { Matahari } \\
\left({ }^{\circ} \mathrm{C}\right)\end{array}$ & $\begin{array}{l}\text { Isc } \\
\text { (V) }\end{array}$ & $\begin{array}{l}\text { Suhu } \\
\text { (Anomali } \\
\text { Cuaca) }\end{array}$ & Tegangan & Keterangan \\
\hline 1 & 9,5 & 831,4 & 4,94 & 49,2 & 21,2 & Cerah \\
\hline 2 & 9,6 & 895,4 & 4,99 & 51,2 & 20,8 & Cerah \\
\hline 3 & 10,0 & 888,7 & 4,89 & 49,6 & 20,9 & Cerah \\
\hline 4 & 10,1 & 854,0 & 4,91 & 50,0 & 20,9 & Cerah \\
\hline 5 & 10,1 & 821,2 & 4,88 & 50,4 & 21,0 & Cerah \\
\hline 6 & 10,2 & 898,6 & 4,81 & 49,0 & 21,2 & Cerah \\
\hline 7 & 10,2 & 935,7 & 5,03 & 50,8 & 20,9 & Cerah \\
\hline 8 & 10,3 & 900,2 & 5,07 & 51,6 & 20,7 & Cerah \\
\hline 9 & 10,3 & 731,9 & 4,93 & 50,8 & 20,6 & Cerah \\
\hline 10 & 10,4 & 688,8 & 5,4 & 48,0 & 21,0 & Cerah \\
\hline 11 & 10,4 & 995,8 & 5,5 & 49,7 & 21,2 & Cerah \\
\hline 12 & 10,5 & 996,0 & 5,7 & 52,7 & 20,7 & Cerah \\
\hline 13 & 10,5 & 978,4 & 5,62 & 54,8 & 20,8 & Cerah \\
\hline 14 & 10,6 & 762,8 & 5,08 & 48,1 & 21,0 & Cerah \\
\hline 15 & 11,0 & 783,7 & 5,1 & 42,8 & 21,3 & Cerah \\
\hline 16 & 11,1 & 792,3 & 5,12 & 42,5 & 21,7 & Cerah \\
\hline 17 & 11,1 & 835,7 & 4,92 & 49,0 & 21,1 & Cerah \\
\hline 18 & 11,2 & 874,5 & 5,11 & 49,7 & 20,1 & Cerah \\
\hline 19 & 11,2 & 892,1 & 5,39 & 52,1 & 21,1 & Cerah \\
\hline 20 & 11,3 & 894,4 & 4,92 & 53,4 & 20,9 & Cerah \\
\hline 21 & 11,3 & 915,4 & 5,52 & 53,0 & 21,1 & Cerah \\
\hline
\end{tabular}


Vol. 10, No. 2, Desember 2020, P-ISSN 2356-1505, E-ISSN 2656-9175

https://doi.org/10.33322/sutet.v10i2.1291

\begin{tabular}{|c|c|c|c|c|c|c|}
\hline 22 & 11,4 & 851,8 & 5,18 & 48,4 & 20,8 & cerah \\
\hline 23 & 11,4 & 864,7 & 5,28 & 47,6 & 21,4 & Cerah \\
\hline 24 & 11,5 & 786,9 & 4,93 & 50,1 & 20,9 & Cerah \\
\hline 25 & 11,5 & 799,5 & 4,95 & 52,9 & 20,8 & Cerah \\
\hline 26 & 11,6 & 742,6 & 4,88 & 47,5 & 20,9 & Cerah \\
\hline 27 & 12,0 & 728,0 & 4,92 & 43,6 & 21,3 & Cerah \\
\hline 28 & 12,1 & 771,3 & 4,98 & 49,6 & 21,1 & Cerah \\
\hline 29 & 12,1 & 793,6 & 5,12 & 52,5 & 20,9 & Cerah \\
\hline 30 & 12,2 & 730,1 & 4,87 & 47,8 & 21,2 & Cerah \\
\hline 31 & 12,2 & 767,1 & 5,16 & 50,2 & 21,2 & Cerah \\
\hline 32 & 12,3 & 775,7 & 5,12 & 49,6 & 21,0 & Cerah \\
\hline 33 & 12,3 & 660,7 & 5,01 & 50,6 & 21,0 & Cerah \\
\hline 34 & 12,4 & 731,8 & 5,2 & 49,1 & 20,6 & Cerah \\
\hline 35 & 12,4 & 744,1 & 5,15 & 44,2 & 21,2 & Cerah \\
\hline 36 & 12,5 & 762,6 & 5,13 & 42,5 & 20,6 & Cerah \\
\hline 37 & 12,5 & 717,3 & 5,05 & 43,3 & 21,3 & Cerah \\
\hline 38 & 12,6 & 733,7 & 5,09 & 44,7 & 21,2 & Cerah \\
\hline 39 & 13,0 & 812,7 & 5,14 & 51,9 & 20,7 & Cerah \\
\hline 40 & 13,1 & 724,1 & 5,01 & 41,5 & 21,0 & Cerah \\
\hline 41 & 13,1 & 705,0 & 4,93 & 37,9 & 21,7 & Cerah \\
\hline 42 & 13,2 & 748,3 & 5,08 & 43,6 & 21,4 & Cerah \\
\hline 43 & 13,2 & 796,8 & 5,05 & 51,0 & 21,1 & Cerah \\
\hline 44 & 13,3 & 782,7 & 5,02 & 47,2 & 21,1 & Cerah \\
\hline 45 & 13,3 & 773,8 & 5,1 & 44,9 & 21,2 & Cerah \\
\hline 46 & 13,4 & 769,2 & 5,05 & 44,7 & 21,1 & Cerah \\
\hline 47 & 13,4 & 754,1 & 4,98 & 46,5 & 21,1 & Cerah \\
\hline 48 & 13,5 & 712,7 & 4,91 & 40,7 & 21,3 & Cerah \\
\hline 49 & 13,5 & 729,4 & 4,94 & 41,6 & 21,4 & Cerah \\
\hline 50 & 13,6 & 714,2 & 4,96 & 39,5 & 21,1 & Cerah \\
\hline 51 & 14,0 & 736,9 & 5,04 & 42,1 & 21,2 & Cerah \\
\hline 52 & 14,1 & 762,2 & 5,12 & 44,2 & 21,4 & Cerah \\
\hline 53 & 14,1 & 754,8 & 5,08 & 42,3 & 21,1 & Cerah \\
\hline 54 & 14,2 & 705,3 & 4,93 & 39,3 & 21,2 & Cerah \\
\hline 55 & 14,2 & 711,4 & 4,97 & 38,6 & 21,4 & Cerah \\
\hline 56 & 14,3 & 748,1 & 5,02 & 41,2 & 21,3 & Cerah \\
\hline 57 & 14,3 & 716,5 & 4,96 & 38,5 & 21,2 & Cerah \\
\hline 58 & 14,4 & 696,7 & 4,92 & 36,5 & 21,1 & Berawan \\
\hline 59 & 14,4 & 695,3 & 4,83 & 36,1 & 21,3 & Berawan \\
\hline 60 & 14,5 & 687,8 & 4,87 & 36,9 & 21,0 & Cerah \\
\hline 61 & 14,5 & 660,8 & 4,82 & 37,0 & 21,4 & Berawan \\
\hline 62 & 14,6 & 662,5 & 4,86 & 33,9 & 21,1 & Berawan \\
\hline 63 & 15,0 & 650,9 & 4,84 & 34,8 & 21,2 & Berawan \\
\hline
\end{tabular}


Modul Surya yang digunakan memiliki spesifikasi :
a. Model no
: GH100P-18
b. Rated Power (Pmax)
$: 100 \mathrm{~W}$
c. Open Circuit Voltage (Voc)
: $21,6 \mathrm{~V}$
d. Short Circuit Current (Isc)
: $5,99 \mathrm{~A}$
e. Voltage at Pmax (Vmp)
$: 18 \mathrm{~V}$
f. Current at Pmax (Imp)
$: 5,56 \mathrm{~A}$
g. Weight
$: 7 \mathrm{Kg}$
h. Dimension
: $1020 * 670 * 30(\mathrm{~mm})$

Terlihat bahwa dari tabel 1 saat suhu naik maka irradiance juga naik. Naik turunnya data ini disebabkan karena kenaikan irradiance tidak langsung diikuti kenaikan suhu begitu pula sebaliknya, penurunan pada irradiance tidak langsung diikuti dengan penurunan suhu. Hal ini disebabkan karena pada irradiance pada saat penelitian dapat berubah dengan sangat cepat sedangkan pada suhu permukaan modul surya membutuhkan waktu untuk naik dan turunnya.

Dengan menggunakan persamaan 2 dan 4 maka diperoleh hasil daya output dan efisiensi dapat dilihat pada tabel 2.

Tabel 2. Hasil Perhitungan Daya dan Efisiensi

\begin{tabular}{|c|c|c|c|c|}
\hline No. & Waktu & Pout & Suhu & $\eta(\%)$ \\
$\left(\mathrm{W} / \mathrm{m}^{2}\right)$ & $(\mathrm{A})$ & $\left({ }^{\circ} \mathrm{C}\right.$ & $\left({ }^{\circ} \mathrm{C}\right)$ & \\
\hline 1 & 9,5 & 99,49 & 49,2 & 25,12 \\
\hline 2 & 9,55 & 99,64 & 51,2 & 25,16 \\
\hline 3 & 10 & 100,16 & 49,6 & 25,29 \\
\hline 4 & 10,05 & 99,54 & 50 & 25,13 \\
\hline 5 & 10,1 & 100,43 & 50,4 & 25,36 \\
\hline 6 & 10,15 & 99,93 & 49 & 25,24 \\
\hline 7 & 10,2 & 99,87 & 50,8 & 25,22 \\
\hline 8 & 10,25 & 99,70 & 51,6 & 25,17 \\
\hline 9 & 10,3 & 99,53 & 50,8 & 25,13 \\
\hline 10 & 10,35 & 99,79 & 48 & 25,21 \\
\hline 11 & 10,4 & 100,28 & 49,7 & 25,32 \\
\hline 12 & 10,45 & 100,29 & 52,7 & 25,33 \\
\hline 13 & 10,5 & 100,53 & 54,8 & 25,38 \\
\hline 14 & 10,55 & 100,28 & 48,1 & 25,32 \\
\hline 15 & 11 & 99,94 & 42,8 & 25,24 \\
\hline 16 & 11,05 & 99,99 & 42,5 & 25,25 \\
\hline 17 & 11,1 & 99,66 & 49 & 25,16 \\
\hline 18 & 11,15 & 99,97 & 49,7 & 25,21 \\
\hline 19 & 11,2 & 100,08 & 52,1 & 25,27 \\
\hline 20 & 11,25 & 99,74 & 53,4 & 25,08 \\
\hline 21 & 11,3 & 100,17 & 53 & 25,29 \\
\hline & & & & \\
\hline
\end{tabular}




\begin{tabular}{|c|c|c|c|c|}
\hline 22 & 11,35 & 100,20 & 48,4 & 25,31 \\
\hline 23 & 11,4 & 100,56 & 47,6 & 25,39 \\
\hline 24 & 11,45 & 99,95 & 50,1 & 25,23 \\
\hline 25 & 11,5 & 99,87 & 52,9 & 25,22 \\
\hline 26 & 11,55 & 99,95 & 47,5 & 25,24 \\
\hline 27 & 12 & 100,56 & 43,6 & 25,39 \\
\hline 28 & 12,05 & 99,82 & 49,6 & 25,21 \\
\hline 29 & 12,1 & 99,52 & 52,5 & 25,13 \\
\hline 30 & 12,15 & 100,15 & 47,8 & 25,29 \\
\hline 31 & 12,2 & 99,55 & 50,2 & 25,13 \\
\hline 32 & 12,25 & 99,99 & 49,6 & 25,25 \\
\hline 33 & 12,3 & 99,99 & 50,6 & 25,25 \\
\hline 34 & 12,35 & 100,12 & 49,1 & 25,28 \\
\hline 35 & 12,4 & 100,45 & 44,2 & 25,36 \\
\hline 36 & 12,45 & 100,39 & 42,5 & 25,35 \\
\hline 37 & 12,5 & 100,04 & 43,3 & 25,34 \\
\hline 38 & 12,55 & 100,35 & 44,7 & 25,34 \\
\hline 39 & 13 & 99,95 & 51,9 & 25,24 \\
\hline 40 & 13,05 & 100,01 & 41,5 & 25,25 \\
\hline 41 & 13,1 & 100,16 & 37,9 & 25,29 \\
\hline 42 & 13,15 & 100,02 & 43,6 & 25,25 \\
\hline 43 & 13,2 & 99,49 & 51 & 25,12 \\
\hline 44 & 13,25 & 100,57 & 47,2 & 25,39 \\
\hline 45 & 13,3 & 100,47 & 44,9 & 25,37 \\
\hline 46 & 13,35 & 100,16 & 44,7 & 25,29 \\
\hline 47 & 13,4 & 99,92 & 46,5 & 25,23 \\
\hline 48 & 13,45 & 100,40 & 40,7 & 25,35 \\
\hline 49 & 13,5 & 100,43 & 41,6 & 25,36 \\
\hline 50 & 13,55 & 100,47 & 39,5 & 25,37 \\
\hline 51 & 14 & 100,44 & 42,1 & 25,36 \\
\hline 52 & 14,05 & 99,91 & 44,2 & 25,01 \\
\hline 53 & 14,1 & 99,98 & 42,3 & 25,24 \\
\hline 54 & 14,15 & 100,34 & 39,3 & 25,33 \\
\hline 55 & 14,2 & 99,98 & 38,6 & 25,24 \\
\hline 56 & 14,25 & 100,51 & 41,2 & 25,38 \\
\hline 57 & 14,3 & 99,99 & 38,5 & 25,25 \\
\hline 58 & 14,35 & 99,66 & 36,5 & 25,16 \\
\hline 59 & 14,4 & 99,79 & 36,1 & 25,21 \\
\hline 60 & 14,45 & 100,22 & 36,9 & 25,31 \\
\hline 61 & 14,5 & 100,05 & 37 & 25,26 \\
\hline 62 & 14,55 & 100,50 & 33,9 & 25,37 \\
\hline 63 & 15 & 100,11 & 34,8 & 25,28 \\
\hline
\end{tabular}


Dari tabel 2 dapat dilihat bahwa hubungan antara suhu terhadap daya keluaran yaitu berbanding terbalik karena apabila suhu panel surya semakin tinggi maka daya keluaran dari sel surya semakin kecil begitu juga sebaliknya bahwa semakin rendah suhu panel maka semakin besar pula daya keluaran dari panel surya jenis polycristaline ini. Sedangkan efisiensi berkaitan dengan nilai daya keluaran yang telah dihasilkan. Pada pengujian terlihat saat suhu menunjukkan nilai optimal pada range suhu $35^{\circ} \mathrm{C}-50^{\circ} \mathrm{C}$ maka nilai efisiensi akan lebih baik. Tetapi saat suhu melebihi dari $50^{\circ} \mathrm{C}$ maka efisensi akan turun dan menyebabkan output daya keluaran akan berkurang. Pada saat penguijan pada ketika intensitas cahaya matahari pada jam puncaknya, terlihat pada suatu kasus penurunan daya yang terjadi di jam 10.40 pada suhu $49,7^{\circ} \mathrm{C}$ menghasilkan Daya keluaran (Pout) sebesar 100,195 watt dan disaat jam 10.45 suhu pada permukaan sel surya naik mencapai $52,7^{\circ} \mathrm{C}$ nilai Poutnya turun menjadi 99,484 Watt.

\section{KESIMPULAN DAN SARAN}

Dari Penjelasan dan perhitungan yang telah dilakukan, maka dapat disimpulkan bahwa saat kenaikan suhu pada panel surya akan membuat nilai daya keluarannya mengalami penurunan dan pada saat terjadi penurunan suhu maka nilai daya keluarannya akan naik. Hasil pengujian pada pukul 10.40 dengan suhu permukaan panel surya mencapai $49,7^{\circ} \mathrm{C}$ didapatkan hasil daya keluaran $100,195 \mathrm{~W}$ dan pada pukul 10.45 dengan suhu permukaan panel surya mencapai $52,7^{\circ} \mathrm{C}$ didapatkan hasil daya keluaran 99,484 W. Hasil yang didapat pengujian menunjukkan pengaruh temperatur dari permukaan sel surya terhadap nilai daya keluarannya. Sehingga bisa dikatakan suhu dipengaruhi oleh intensitas radiasi matahari yang akan membuat daya (Pout) mengalami kenaikan, kondisi modul surya berjenis poly-crystalline akan bekerja secara optimal pada suhu sekitar $35^{\circ} \mathrm{C}-50^{\circ} \mathrm{C}$ yang terukur pada permukaan sel surya.

\section{UCAPAN TERIMAKASIH}

Penulis mengucapkan terima kasih kepada semua pihak khususnya IT-PLN yang telah memberi dukungan dalam membantu pelaksanaan penelitian ini.

\section{DAFTAR PUSTAKA}

[1] Anggraini, S. (2016). Analisis Perbandingan Daya 2 Panel Dan 4 Panel Pada Sistem PLTS Untuk Charger Di Lingkungan Kampus IST Akprind Menggunakan Matlab 7.10. Jurnal Elektrikal, 58-67.

[2] Assiddiq, H. (2019). Analisis Pengaruh Perubahan Temperatur Panel TerhadapDaya Dan Efisiensi Keluaran Sel Surya Polycristaline. Jurnal IImiah Teknik Mesin.

[3] Demak, R. K. (2016). Komparasi Energi Surya Dengan Lampu Halogen Terhadap Efisiensi Modul Photovoltaic Tipe Multicrystalline. Jurnal Mekanikal, 625-633.

[4] Foster, R. (2010). Solar Energy Renewable Energy And The Environment. Boca Raton : CRC Press LLC.

[5] Hasan, H. (2012). Perancangan Pembangkit Listrik Tenaga Surya Di Pulau Saugi. Jurnal Riset dan Teknologi Kelautan (JRTK) Volume 10, Nomor 2.

[6] Mansyur, I. (2012). Studi Komparatif 2 Model Pembangkit Listrik Sistem Hibrid PLTS Dan PLN/Genset. Prosiding, 1-5. 
[7] Samsurizal, S., Christiono, C., dan Husada, H. (2020). Studi Kelayakan Pemanfaatan Energi Matahari Sebagai Pembangkit Listrik Tenaga Surya Di Dusun Toalang. Setrum: Sistem Kendali-Tenaga-elektronika-telekomunikasi-komputer, 9(1), 75-83.

[8] Pahlevi, R. (2014). Pengujian Karakteristik Panel Surya Berdasarkan Intensitas Tenaga Surya. Jurnal Elektrikal.

[9] Pido, R. (2018). Analisa Pengaruh Pendinginan Sel Surya Terhadap Daya Keluaran Dan Efisiensi. Jurnal Teknologi.

[10] Purwoto, B. H. (2012). Efisiensi Penggunaan Panel Surya Sebagai Sumber Energi Alternatif.

[11] Ramadhan, A. I. (2016). Analisis Desain Sistem Pembangkit Listrik TenagaSurya Kapasitas 50 WP. Jurnal Elektrikal, 59-63.

[12] Samsurizal, A. Makkulau. (2018). Analisa Pengaruh Sudut Kemiringan Terhadap Arus Keluaran Pada Photovoltaic Dengan Menggunakan Regretion Quadratic Method. Jurnal Energi \& Kelistrikan.

[13] Subekti Yuliananda, G. S. (2015). Pengaruh Perubahan Intensitas Matahari Terhadap Daya Keluaran Panel Surya. Jurnal Pengabdian, 194.

[14] Samsurizal, Purwanto, S. D., Fikri, M., \& Christiono, C. (2020). Dampak Bayangan Pada Panel Surya Terhadap Daya Keluaran Photovoltaic. Setrum: Sistem KendaliTenaga-elektronika-telekomunikasi-komputer, 9(2).

[15] Triono, W. (2017). Rancang Bangun Aplikasi Panel Surya Monocrystalline Dan Polycrystalline Pada Penerangan Jalan Umum. Jakarta.

[16] Yohana, E. (2010). Pengaruh Suhu Permukaan Photovoltaic Module 50 Watt Peak Terhadap Daya Keluaran Yang Dihasilkan Menggunakan Reflektor. Rotasi, 14-18.

[17] Makkulau, A., Samsurizal, and Christiono. (2019). Characteristics of Temperature Changes Measurement on Photovoltaic Surfaces Against Quality of Output Current on Solar Power Plants. IEEE. 